\title{
A Test of Association between Working Hour and Work Family Conflict: A Glimpse on Dhaka's Female White Collar Professionals
}

\author{
M Sayeed Alam (Corresponding author) \\ East West University \\ 43 Mohakhali C/A, Dhaka 1212, Bangladesh \\ Tel: 88-1715834418Ｅ-mail: sbl.dhk@gmail.com
}

Kohinoor Biswas

East West University

43 Mohakhali C/A, Dhaka 1212, Bangladesh

Kamrul Hassan

East West University

43 Mohakhali C/A, Dhaka 1212, Bangladesh

\begin{abstract}
As there has been an increasing influx of white collar woman professionals in Dhaka, maintaining work- family balance is becoming more critical day by day. This study particularly attempts to explore the correlation between working hour and work family imbalance. Three FGDs, each with 10 female managers, were conducted, to make a total sample size of 30 . Findings report extensive working hours, per se 9-10 hours a day, as a lethal contributor to work family conflict, whereas shorter working hours (average 5-7 hours) have little or no affect. This study is based on Dhaka city and concentrated on private commercial organizations only. So an extended sample with more coverage is suggested.
\end{abstract}

Keywords: Working hour, Work family conflict, Dhaka

\section{Introduction}

With the increase in dual-income families and employed single parents, conflict between work and family has reached a crisis (Beauregard, 2006). Rhona and Robert N. Rapoport $(1969,1976)$ coined the terms "Dual Career Family" and "Dual Career Couple" (DCC) at that time these have become increasingly significant lifestyles (Greenhaus, 1989; Sekaran, 1983, 1985, 1986).

Work and family are the key domains of life to many people (Whitely and England, 1977), and, not surprisingly, work-family conflict (WFC) research has become a major area in organizational research (Parasuraman and Greenhaus, 2002). Work-family stress has been identified as a major problem for working mothers (Aryee et al, 1999, Ng et al, 2002).

Most family/work research emphasizes the idea that conflict has an impact on individual's emotional and physical condition, thus causing disadvantages for companies due to absenteeism and diminishing productivity (Cooper and Williams, 1994). Not only conflicts between the two fields might affect productivity, spillover theory (Caligiuri and Cascio, 1998) rather suggests that problems in one domain (e.g. home-life) will affect the other (e.g. performance in the job).

There are two types of work-family conflicts (Boyar et al, 2008)

A. "work interfering with family" conflict (WIF); and

B. "family interfering with work" conflict (FIW) (e.g. Carlson et al., 2000; Frone et al., 1992a, 1996; Gutek et al., 1991; Netemeyer et al., 1996). 
Work-family conflict and family-work conflict are distinct, but conceptually related forms of inter-role conflict (Frone et al., 1992; Netemeyer et al., 1996). Work-family conflict refers to "a form of inter-role conflict in which the general demands of, time devoted to, and strain created by the job interfere with performing family-related responsibilities" and family-work conflict refers to "a form of inter-role conflict in which the general demands of, time devoted to, and strain created by the family interfere with performing work-related responsibilities" (Netemeyer et al., 1996).

Both forms of conflict basically result from an individual's attempts to meet an overabundance of demands emanating from the home/family and work domains in which the individuals operate (Boles et al., 2001). The demands coming from one domain make performance of roles in the other domain more difficult. Yavas et al. (2008) contend that three consequences of work-family and family-work conflicts are: emotional exhaustion, poor job performance and higher turnover intentions.

This study targets married women professionals working in Dhaka city and examines their work-family conflict experiences. Western literature abounds on this topic (e.g. Ferber and O'Farrell, 1991; Hochschild, 1997; Pleck, 1977), but relevant information on Bangladesh is rarely available. Unique socio-economic structure of Dhaka city makes this study an interesting one which sheds lights into multiple relationships between husband and wife, children and mother, domestic help and professional women.

2.

\subsection{Conceptual Framework of WFC}

Different researchers define the conceptual framework of WFC differently. The conceptual framework developed by Yavas, et.al, (2008) is shown in Figure 1.

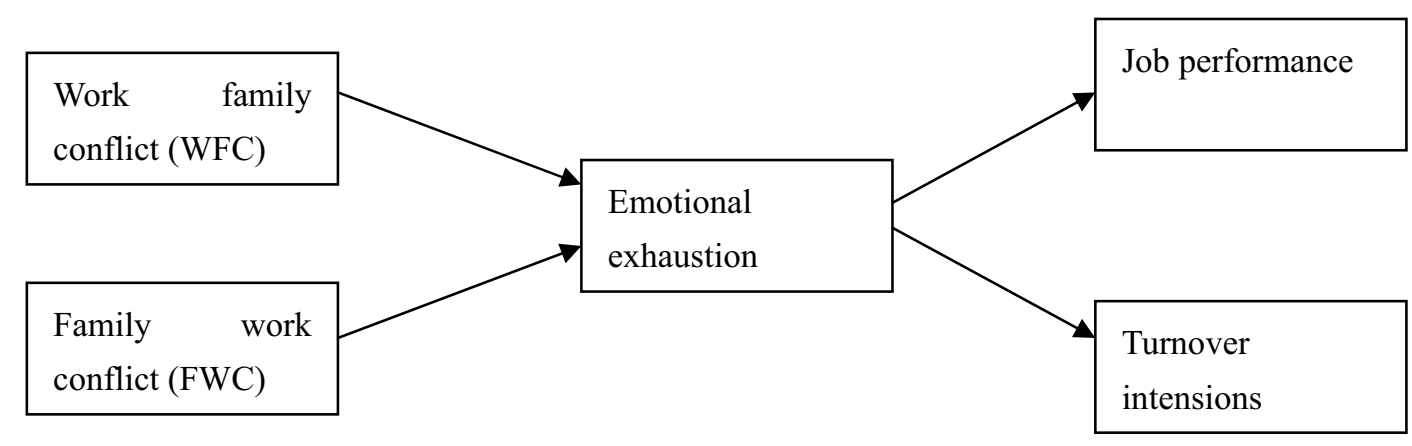

\begin{tabular}{|l|l|}
\hline $\begin{array}{l}\text { Control variables } \\
\text { Age, education, marital } \\
\text { status, no of children, } \\
\text { tenure }\end{array}$ & $\begin{array}{l}\text { Moderator } \\
\text { Gender }\end{array}$ \\
\hline
\end{tabular}

According to this model developed by Yavas, et.al, (2008) inter-role conflicts emanating from the demands of the two universal domains of adult life, work and family, lead to emotional exhaustion. According to this model, emotional exhaustion results in poor job performance and a higher propensity to leave the organization. Hence, the key underlying premise of this model is that work-family conflict and family-work conflict impact the two critical job outcomes of performance and turnover intentions both directly as well as indirectly through the mediating role of emotional exhaustion.

According to Kim's (2001), work-family conflict arises from factors within the work domain and family domain, the research model on WFC is 


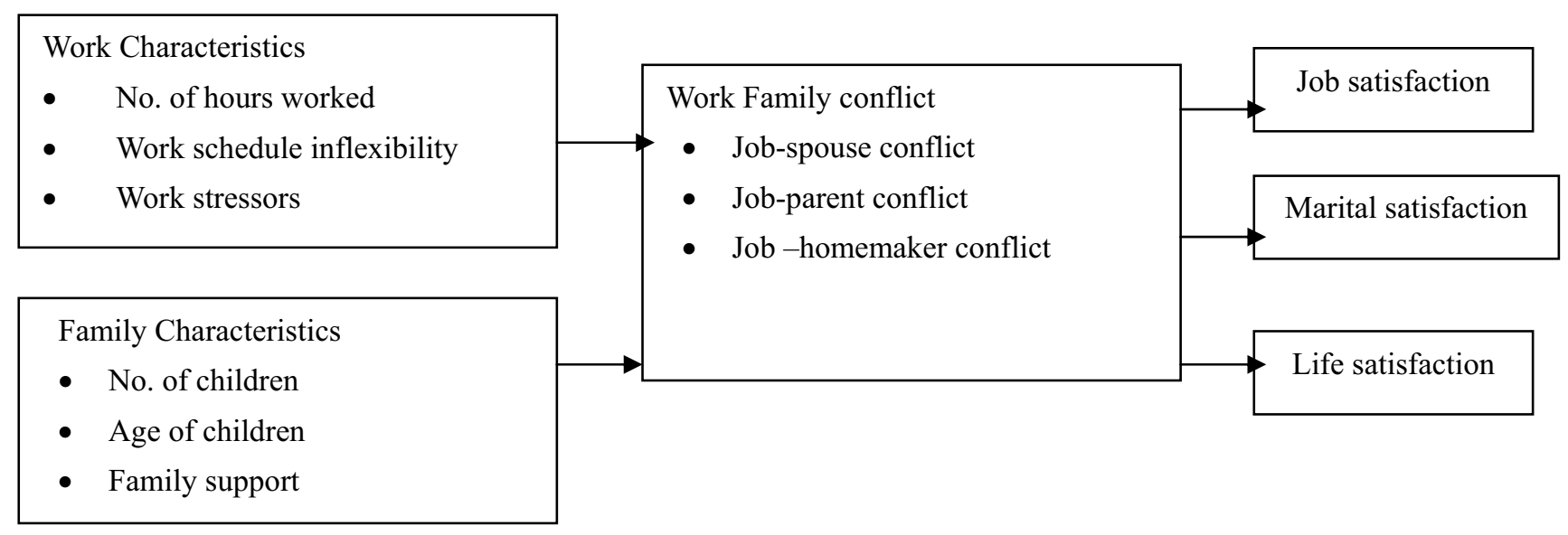

Researchers have come to implicitly agree that increases in demand are a primary cause of "work interfering with family" conflict (WIF) and "family interfering with work" conflict (FIW) (e.g. Carlson and Kacmar, 2000; Parasuraman et al., 1996). Excessive work time has long been seen as the major culprit affecting work-family balance (Pleck et al., 1980).

The work-family literature has traditionally assumed that variables associated with the family domain (e.g. childcare, household work) predict Family to Work Conflict (FWC), and that work domain variables (e.g. hours worked weekly, job autonomy) predict Work to family conflict (WFC) (Beauregard , 2006).

The number of hours spent weekly in work activities has been shown to have a positive relationship with WFC (Fu and Shaffer, 2001). Expectations held by superiors and co-workers for an employee to prioritize the work by assuming increased job responsibilities and extending performance of the work role beyond normal working hours have also been shown to contribute to WFC (Major et al., 2002).

Parental demand can affect work-family conflict. Parents tend to experience more work-family conflict than non-parents as they need to spend greater amount of time at home taking care of their children. Parental demand is measured by the number of children and their age. Younger children will demand more of their parents' time. And large families are likely to be more time demanding than small families (Greenhaus and Beutell, 1985). Pleck et al. (1980) reported that parents experience more work-family conflict than married couples without children.

The supportive behavior of family members can help to buffer work-family conflict is experienced by working women. The support can be attitude, emotional or instrumental support (Kim and Ling 2001). Emotional support refers to the display of sympathetic and caring behavior such as taking interest in the spouse's work, willingness to listen, and giving advice (Kim and Ling 2001). Instrumental support is the provision of actual assistance to help in task accomplishment, which includes helping out in household chores and childcare. Instrumental support can reduce time pressure and parental demand that causes work-family conflict (King et al., 1995).

\subsection{Outcomes of Work to Family Conflict (WFC)}

Emotional exhaustion is the first stage of the burnout syndrome (Cordes and Dougherty, 1993; Maslach and Jackson, 1981) and it occurs when an individual faces seemingly overwhelming demands on his/her time and energy. Depletion of emotional resources and a lack of energy characterize emotional exhaustion (Gaines and Jermier, 1983). Precepts of three well-endorsed theoretical frameworks (inter-role conflict theory, identity theory, and conservation of resources -COR theory) suggest that work-family and family-work conflicts can lead to emotional exhaustion.

Study on women entrepreneurs, by Arora et al. (1990) found a negative relationship between work-family conflict and job/business satisfaction. Similar results for Singapore women professionals are obtained by Aryee (1992). Pleck et al. (1980) reported that when work-family conflict existed, the working women experience less job satisfaction.

Empirical research reveals that work-family conflict has a detrimental impact on performance (Aryee, 1992; Frone etal., 1997; Netemeyer etal., 2004). Anecdotal evidence by the Family and Work Institute as well indicates that employees who cannot balance their work demands with home and family responsibilities experience negative spillovers resulting in decreased job performance (Netemeyer et al., 2003). There is also evidence indicating that family-work conflict decreases employees' work-related performance (Frone et al., 1997; Netemeyer et al., 2004).

\section{Focus of this study}

The objective of this research is to identify to what extent the married women managers of Dhaka face the work family conflict with respect to working hours. This study mainly has two focal points:

A. Identify the impact of working hours (both short and long working hours) on work family conflict. 
B. Develop a model on the basis of the findings on A

\section{Methodology}

Data were obtained from three FGDs. Each focus group consisted of 10 members. Face-to face interviews were taken separately with each group for one hour. Each focus group maintained consistency on two variables: working hours and average monthly income. The first focus group consists of teaching professionals whose working hours is 5- 7 hours per day; the other two focus groups are composed of members from corporate houses whose working hours range from 9-10 hours a day. The sample constituted a total of thirty female managers.

A structured questionnaire was used to collect some basic information of the selected thirty respondents (years in service, levels of education, age, no. of children, sources of child care support). The target population of this study was married women managers in Dhaka city. A manger means who has the authority to delegate and who has some subordinates to supervise. During focus group discussions all opinions, comments and suggestions were noted.

\section{Hypothesis of this study}

For short working hour

$\mathrm{H}_{1}$ : Short working hours has impact on work family conflict

For long working hour

$\mathrm{H}_{2}$ : Long working hours has impact on work family conflict

The linear relationship between the dependent and the independent variables was determined through ordinary least-square (OLS) regression. Here two different equations were constructed to find the regression results of the above mentioned hypothesis. Equation of for the first hypothesis

$$
\mathrm{WFC}_{\mathrm{Sh}}=\beta_{0}+\beta_{1} \mathrm{~W}_{\mathrm{Sh}}+\mathrm{u}_{\mathrm{h}}
$$

Equation -1 attempts to find out the results on short working hours $\left(\mathrm{W}_{\mathrm{Sh}}\right)$ influences on Work family conflict $\left(\mathrm{WFC}_{\mathrm{Sh}}\right)$

$$
\mathrm{WFCLh}=\beta 0+\beta 1 \mathrm{WLh}+\mathrm{uh}
$$

Equation -2 attempts to find out the results on long working hours $\left(\mathrm{W}_{\mathrm{Lh}}\right)$ influences on Work family conflict $\left(\mathrm{WFC}_{\mathrm{Lh}}\right)$

\section{Sample Profile}

\subsection{Respondent profile (working 5-7 hours per day, two days weekly holidays)}

The respondents of this category are in academia. 40 percent of them are having length of service between 2 to 5 years, 60 percent are in service for more than 5 years. All of the respondents are master degree holders. 30 percent respondents are having one child, 60 percent are having two and 10 percent have three children. 30 percent of the respondents reported that their own parents were taking care of their children while they were at job, 40 percent depended on their parent-in-laws for their children care and 30 percent respondent depended on domestic help (Table 1)

\subsection{Respondent profile (working 9-10 hours per day, one/ two days weekly holidays)}

The respondent of this category are 40 percentage entry level managers in bank, 35 percentage entry level managers in other corporate houses, 15 percentage mid level managers from telecom sector, 10 percentage are senior level executives from banks. 60 percent are having service length of 2-5 years, 20 percent are in service for more than 5 years. All of the respondents are master degree holders. 20 percent respondents have no child, 80 percent are mother of two children. 40 percentage respondents said that their own parents were taking care of their children while they were at job, this percentage is 60 who depended on their parent-in-laws for children care. (Table 2)

\section{Findings from the Focus Group Discussions}

\subsection{Short Working Hours}

The respondents working for 5-7 hours a day did not consider working hours as a factor to affect work and family balance. 60 percent respondents disagreed with the statement "Working hours positively associated with work -family conflict". Whereas 20 percent respondents of this group agreed with the concept that working hours affect the work family balance. The findings are shown in the Table 3 . The equation is not significant $\mathrm{p}$ value is more than 0.05 at $95 \%$ confidence interval. The coefficient of determination $\left(\mathrm{R}^{2}\right)$ indicates that only $34 \%$ of the total variation in the dependent variable is account for independent variable, while remaining $66 \%$ is account for other variables. Short working hours has no impact on Work Family Conflict). The complete results are shown in the table $-\mathrm{V}$

\section{Few comments of the respondents (Short working hours)}

.......one respondent who was a teacher in a university shared to have a well balanced life between work and family as she could give ample time to her family. She rather opined that having the identity of a professional earned her social status 
which in turn would spill over as a sense of completeness into her family domain to give her a more meaningful and productive life.

\subsection{Long working hours (9-10 hours daily)}

On the other hand, woman managers in corporate sector having long working hours (9-10 hours daily) reflected a different picture. 80 percent of the managers working for 9-10 hours daily, agreed that time is a crucial factor for work family imbalance. The findings are shown in the following table: IV

The equation is significant $\mathrm{p}$ value is less than 0.01 at $99 \%$ confidence interval. The coefficient of determination $\left(\mathrm{R}^{2}\right)$ indicates that only $75 \%$ of the total variation in the dependent variable is account for independent variable, while remaining $25 \%$ is account for other variables. Long working hours has impact on Work Family Conflict. (Table-VI)

\section{Few comments of the respondents (Short working hours)}

......one mother having two small children of less than 5 years shared her emotional strain. Despite having moral support from her husband almost everyday when she reached home pretty late after dusk, she had to face increasing difficulty to satisfy the ever increasing role expectations from different stakeholders of her life; namely children and in-laws.

...... One respondent said that she had to stay with her parents in law. After returning home she had to address different family and social issues raised by her mother in law, or sister in law. She said that after joining work for the last two years it seemed to her that she was working round the clock and she failed to watch any movie as she failed to manage any time.

\section{Model developed from this study}

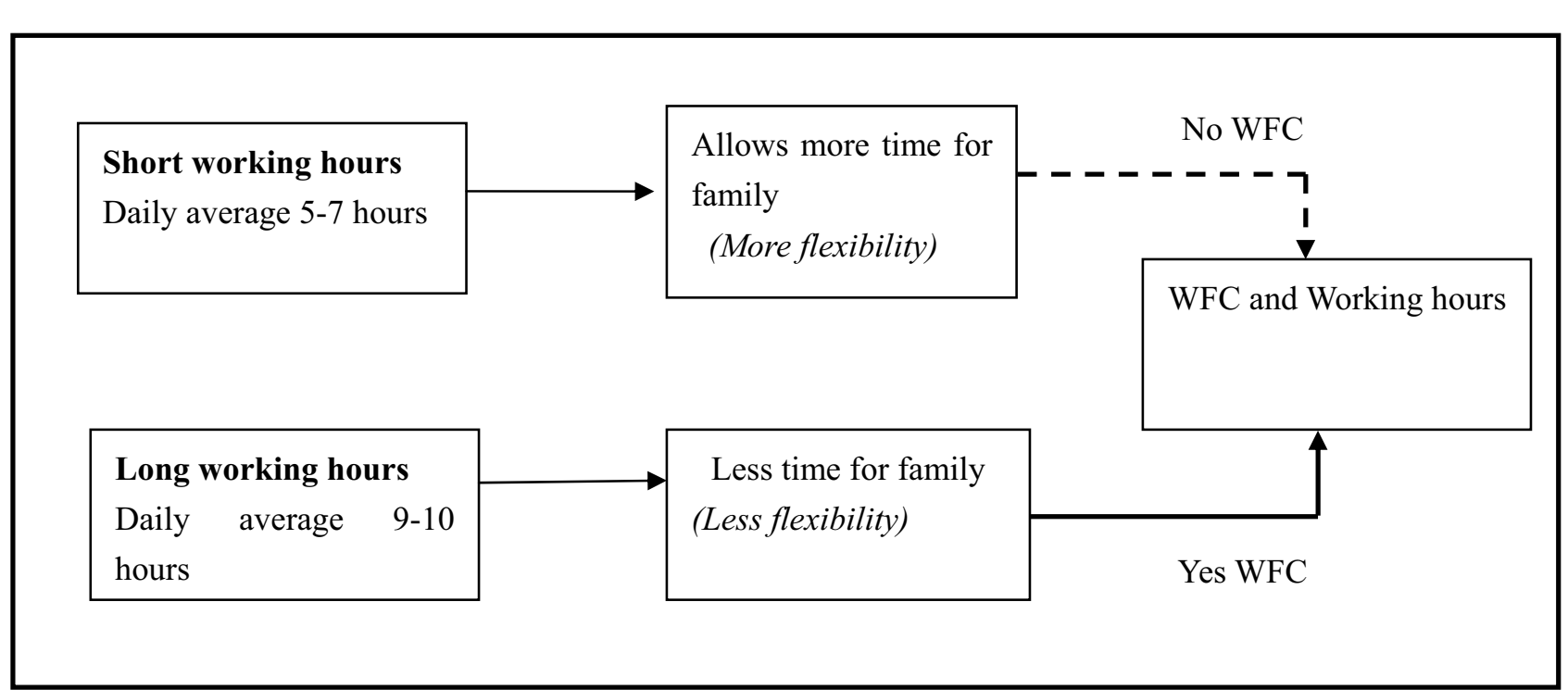

\section{Conclusion}

At the personnel level WFC precipitates to emotional exhaustion, at the organizational level it is translated into potential loss of female talent. Since WFC causes diminished job performance leading to turnover intentions, this might ultimately cost an organization in terms of loss of female talent. With the growing size of female white collar professionals at work place in Dhaka, the issue of work family conflict is gaining momentum. As literatures available on the Western world reveal work domain variables; such as working hours, schedule inflexibility or work stressors, to have association with work family conflict, study of the same sort has relevance in the socio-economic context of Dhaka. Two main branches of WFC area- work interfering with family conflict (WIF) and family interfering with work conflict (FIW) have widely been studied in the Western context, while a little is known in the socio-economic scenario of Dhaka. Dhaka, being the cosmopolitan city, shares some important commonness with other economic hubs of the developed world. This study has taken into account the impact of single work domain variable; i.e. working hour on work family conflict.

This study approves the association between working hour and WFC. 99 percent of the woman managers reported to have been suffering from the symptoms of WFC because of 9 to 10 hours of work everyday. While only 20 percent involved in teaching reported so.

Woman managers feel a strong two-way pull to maintain balance between work and family. With superior position comes more responsibility demanding for extended working hours leading to greater potential of WFC specially when support from family members remain very low or non-existent. 
This study may further be elaborated with bigger sample size to look into relationships among other variables in work and family domain. The picture of struggle behind WFC can then be well portrayed with implications for organization.

\section{References}

Arora, R., Hartman, R.I. and Stoner, C.R. (1990). Work-home role conflict in female owners of small business: an exploratory study. Journal of Small Business Management, Vol. 28, No. 1, pp. 30-38.

Aryee, S. (1992). Antecedents and outcomes of work-family conflict among married professional women: evidence from Singapore. Human Relations, Vol. 45, No. 2, pp. 813-837.

Aryee, S. (1992). Antecedents and outcomes of work-family conflict among professional women: evidence from Singapore. Human Relations, Vol. 45, No. 8, pp. 813-837.

Aryee, S., Luk, V., Leung, A. and Lo, S. (1999). Role stressors, inter-role conflict, and well-being: the moderating influence of spousal support and coping behaviors among employed parents in Hong Kong. Journal of Vocational Behavior, Vol. 54, pp. 259-278.

Beauregard Alexandra T. (2006). Are Organizations Shooting themselves in the foot? Work place contribution to familyto -work conflict. Equal Opportunities International, Vol. 25, No. 5, pp.336-353.

Boles, J.S., Howard, W.G. and Donofrio, H.H. (2001). An investigation into the inter-relationships of work-family conflict, family-work conflict and work satisfaction. Journal of Managerial Issues, Vol. 13, No. 3, pp. 376-390.

Boyar L. Scott, Maertz P Carl Jr, Mosley C. Donald Jr, Carr C. Jon. (2008). The Impact of Work/family demand on work family conflict. Journal of Mechanical Psychology, Vol. 23, No. 3, pp 215-235.

Boyar, S.L., Maertz, C.P. Jr, Pearson, A.W. and Keough, S. (2003). Work-family conflict: a model of linkages between work and family domain variables and turnover intentions. Journal of Managerial Issues, Vol. 15, No. 2, pp. 175-190.

Caligiuri, P. and Cascio, W.F. (1998). Can we send her there? Maximising the success of western women on global assignments. Journal of World Business, Vol. 33, No. 4, pp. 394-416.

Carlson, D.S. and Kacmar, K.M. (2000). Work-family conflict in the organization: do life role values make a difference? Journal of Management, Vol. 26, pp. 1031-1054.

Cooper, C.L. and Williams, S. (1994). Creating Healthy Work Organizations, Wiley, Chichester.

Cordes, C.L. and Dougherty, T.W. (1993). A review and an integration of research on job burnout. Academy of Management Review, Vol. 18, No. 4, pp. 621-56.

Ferber, M.A. and O'Farrell, B. (1991). Work and Family:Policies for a Changing Workforce, National Academy Press, Washington, DC.

Frone, M.R., Russell, M. and Barnes, G.M. (1996). Work-family conflict, gender, and health-related outcomes: a study of employed parents in two community samples. Journal of Occupational Health Psychology, Vol. 1, pp. 57-69.

Frone, M.R., Russell, M. and Cooper, M.L. (1992). Antecedents and outcomes of work-family conflict: testing a model of the work-family interface. Journal of Applied Psychology, Vol. 77, No. 1, pp. 65-78.

Frone, M.R., Russell, M. and Cooper, M.L. (1992a). Antecedents and outcomes of work-family conflict: testing a model of the work-family interface. Journal of Applied Psychology, Vol. 77, pp. 65-78.

Frone, M.R., Yardley, J.K. and Markel, K.S. (1997), "Developing and testing an integrative model of the work-family interface", Journal of Vocational Behavior, Vol. 50, No. 2, pp. 145-167.

$\mathrm{Fu}$, C.K. and Shaffer, M.A. (2001). The tug of work and family: direct and indirect domain-specific determinants of WFC. Personnel Review, Vol. 30, No. 5, pp. 502-22.

Gaines, J. and Jermier, J.M. (1983). Emotional exhaustion in a high stress organization. Academy of Management Journal, Vol. 26, No. 4, pp. 567-586.

Grandey, A.A. and Cropanzano, R. (1999). The conservation of resources model applied to work-family conflict and strain. Journal of Vocational Behavior, Vol. 54, No. 2, pp. 350-370.

Greenhaus, J.H. (1989). Sources of work-family conflict among two-career couples. Journal of Vocational Bahavior, Vol. 34, No. 2, pp. 133-53.

Greenhaus, J.H. and Beutell, N.J. (1985). Sources of conflict between work and family roles", Academy of Management Review, Vol. 10, No. 1, pp. 76-88.

Greenhaus, J.H. and Beutell, N.J. (1985). Sources of conflict between work and family roles. Academy of Management Review, Vol. 10, pp. 76-88. 
Gutek, B.A., Searle, S. and Klepa, L. (1991). Rational versus gender role explanations for work-family conflict. Journal of Applied Psychology, Vol. 76, pp. 560-8.

Hochschild, A.R. (1997). The Time Bind: When Work Becomes Home and Home Becomes Work, Metropolitan Books, New York, NY.

Holahan, C.K. and Gilbert, L.A. (1979). Conflict between major life roles: women and men in dual career couples. Human Relations, Vol. 32, No. 6, pp. 451-67.

Hughes, D., Galinsky E. and Morris, A. (1992). The effects of job characteristics on marital quality: specifying linking mechanisms. Journal of Marriage and the Family, Vol. 54, No. 1, pp. 31-42.

Kim Siew Lee Fean, Ling Seow Choo. (2001). Work-Family conflict of women entrepreneurs in Singapore. Women in Management review, Vol. 16, No. 5, pp-204-221.

King, L.A., Mattimore, L.K., King, D.W. and Adams, G.A. (1995). Family support inventory for workers: a new measures of perceived social support from family members. Journal of Organizational Behavior, Vol. 16, pp. 235-58.

Major, V.S., Klein, K.J. and Ehrhart, M.G. (2002). Work time, work interference with family, and psychological distress Journal of Applied Psychology, Vol. 87, No. 3, pp. 427-36.

Maslach, C. and Jackson, S.E. (1981). The measurement of experienced burnout. Journal of Occupational Behavior, Vol. 2 , No. 2, pp. 99-113.

Netemeyer, R.G., Boles, J.S. and McMurrian, R. (1996). Development and validation of work-family conflict and family-work conflict scales. Journal of Applied Psychology, Vol. 81, pp. 400-10.

Netemeyer, R.G., Brashear-Alejandro, T. and Boles, J.S. (2004). A cross-national model of job-related outcomes of work role and family role variables: a retail sales context. Journal of the Academy of Marketing Science, Vol. 32, No. 1, pp. 49-60.

Netemeyer, R.G., Maxham, J.G. and Pullig, C. (2003). Work-family conflict, job stress, and customer service performance. Working paper, McIntire School of Commerce, The University of Virginia, Charlottesville, VA.

Ng, C.W., Fosh, P. and Naylor, D. (2002). Work-family conflict for employees in an East Asian airline: impact on career and relationship to gender. Economic and Industrial Democracy, Vol. 23, No. 1, pp. 67-105.

Parasuraman, S. and Greenhaus, J.H. (2002). Toward reducing some critical gaps in work-family research. Human Resource Management Review, Vol. 12, pp. 299-312.

Parasuraman, S., Purohit, Y.S. and Godshalk, V.M. (1996). Work and family variables, entrepreneurial career success, and psychological well-being. Journal of Vocational Behavior, Vol. 48, pp. 275-300.

Pleck, J.H. (1977). The work-family role system. Social Problems, Vol. 24, pp. 417-27.

Pleck, J.H., Staines, G.L. and Lang, L. (1980), "Conflicts between work and family life. Monthly Labor Review, March, pp. 29-32.

Rapoport, R. and Rapoport, R.H. (1969). The dual-career family. Human Relations, Vol. 22, No. 1, pp.3-30.

Rapoport, R. and Rapoport, R.N. (1976). Dual Career Families, Re-examined. New Integration of Work and Family, M Robertson, London.

Sekaran, U. (1983). Factors influencing the quality of life in dual-career families. Journal of Occupational Psychology, Vol. 56, No. 2, pp. 161-74.

Sekaran, U. (1985). The paths of mental health. Journal of Occupational Psychology, Vol. 58, No. 2, pp. 129-37.

Sekaran, U. (1986). Dual-Career Families - Contemporary Organizational and Counseling Issues, Jossey-Bass, San Francisco, London.

Ursano, R.J., Grieger, T.A. and McCarroll, J.E. (1996). Prevention of posttraumatic stress: consultation, training, and early treatment. In Van der Kolk, B.A., McFarlane, A.C. and Weisaeth, L. (Eds), Traumatic Stress: The Effects of Overwhelming Experience on Mind, Body, and Society, Guildford Press, New York, pp. 441-62.

Whitely, W. and England, G.W. (1977). Managerial values as a reflection of culture and the process of industrialization. Academy of Management Journal, Vol. 20, pp. 439-53.

Yavas Ugur, Babakus, Karatepe M. Osman. (2008). Attitudinal and behavioral consequences of work-family conflict and family-work conflict does gender matter? International Journal of Service Industry Management, Vol. 19, No. 1, pp. 7-31. 


\section{Appendix}

Table 1. Respondent profile on basic information (working hour 5-7 hours)

\begin{tabular}{|c|c|c|c|c|}
\hline Academic degree & Length of service & No. of Children & Children care & House hold support \\
\hline $\begin{array}{c}100 \text { percent in } \\
\text { teaching profession } \\
\text { with Master degree }\end{array}$ & $\begin{array}{c}40 \text { percentage with } \\
2-5 \text { years }\end{array}$ & $\begin{array}{c}30 \text { percent having one } \\
\text { child }\end{array}$ & $\begin{array}{c}30 \text { percent receive } \\
\text { support from parents }\end{array}$ & $\begin{array}{c}90 \text { percent domestic } \\
\text { help }\end{array}$ \\
\hline & $\begin{array}{c}50 \text { percentage more } \\
\text { than } 5 \text { years }\end{array}$ & $\begin{array}{c}60 \text { percentage with } \\
\text { two children }\end{array}$ & $\begin{array}{c}40 \text { percent receive } \\
\text { support from parent- } \\
\text { in-laws }\end{array}$ & $\begin{array}{c}10 \text { percent } \\
\text { supported by self }\end{array}$ \\
\hline & $\begin{array}{c}10 \text { percentage } \\
\text { working more than } 10\end{array}$ & $\begin{array}{c}10 \text { percentage with } \\
\text { three children }\end{array}$ & $\begin{array}{c}30 \text { percentage take } \\
\text { support from } \\
\text { domestic help }\end{array}$ & \\
\hline
\end{tabular}

Table 2. Respondent profile on basic information (working hours 9-10 hours)

\begin{tabular}{|c|c|c|c|c|c|}
\hline $\begin{array}{c}\text { Respondent } \\
\text { nature of job }\end{array}$ & $\begin{array}{c}\text { Academic } \\
\text { degree }\end{array}$ & Length of service & $\begin{array}{c}\text { No. of } \\
\text { Children }\end{array}$ & Children care & House hold support \\
\hline $\begin{array}{c}40 \text { percentage } \\
\text { Bankers }\end{array}$ & $\begin{array}{c}\text { All of the } \\
\text { respondents are } \\
\text { Master degree } \\
\text { holder }\end{array}$ & $\begin{array}{c}20 \text { percentage } \\
\text { working for less } \\
\text { than 2 years } \\
\text { no children }\end{array}$ & $\begin{array}{c}20 \text { percent with } \\
\text { depend on } \\
\text { parent-in-laws }\end{array}$ & $\begin{array}{c}\text { percentage } \\
\text { domestic staff }\end{array}$ \\
\hline $\begin{array}{c}35 \text { percentage } \\
\text { entry level } \\
\text { managers in } \\
\text { other corporates }\end{array}$ & & $\begin{array}{c}60 \text { percentage } \\
\text { working for } 2-5 \\
\text { years }\end{array}$ & $\begin{array}{c}80 \text { percentage } \\
\text { with two } \\
\text { children }\end{array}$ & $\begin{array}{c}40 \text { percentage } \\
\text { receive support } \\
\text { from own } \\
\text { parents }\end{array}$ & \\
\hline $\begin{array}{c}15 \text { percentage } \\
\text { mid level } \\
\text { mangers from } \\
\text { telecom }\end{array}$ & & $\begin{array}{c}20 \text { percentage } \\
\text { working for more } \\
\text { than } 10 \text { years }\end{array}$ & & & \\
\hline $\begin{array}{c}10 \text { percentage } \\
\text { senior mangers } \\
\text { from bank }\end{array}$ & & & & & \\
\hline
\end{tabular}

Table 3. Less working hours and work family balance

\begin{tabular}{|c|c|c|c|c|}
\hline \multirow{2}{*}{} & \multicolumn{2}{|c|}{$\begin{array}{c}\text { Working hours positively associated with work -family } \\
\text { conflict }\end{array}$} & Agree \\
\cline { 2 - 5 } & Disagree & Neutral & 2 & 10 \\
\hline $\begin{array}{l}\text { Average daily Daily 5-7 hours } \\
\text { working hours } \\
\text { Total }\end{array}$ & 6 & 2 & 2 & 10 \\
\hline
\end{tabular}

Table 4. Long working hours and work family balance

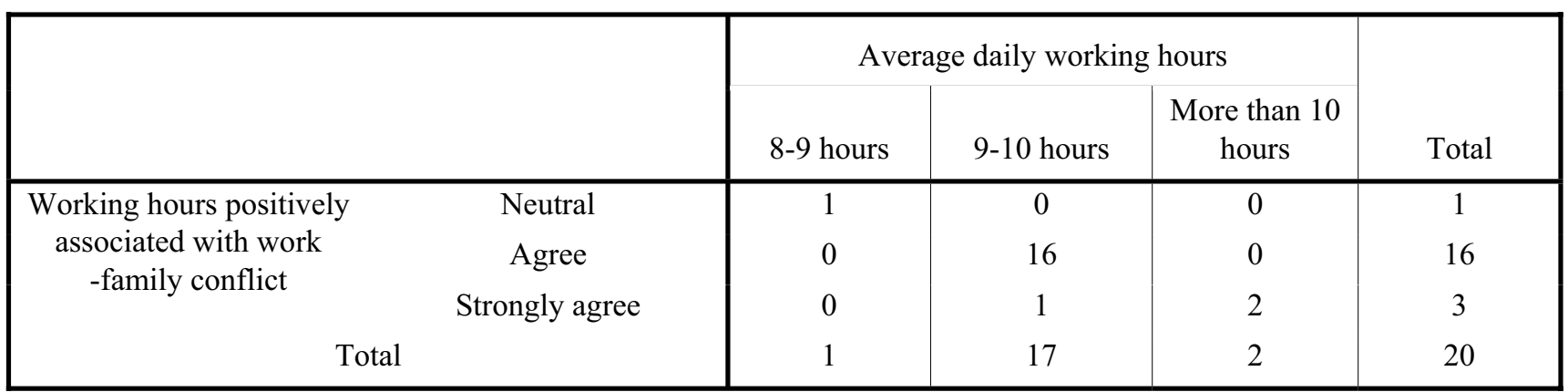


Table 5. Output Regression for Short working hours (all observations are used)

\begin{tabular}{|l|l|l|l|l|l|l|}
\hline Equation no -1 & Model & Co efficient & t-value & p-value & F-value & $\mathrm{R}^{2}$ \\
\hline \multirow{2}{*}{ Hypothesis -1 } & Constant & -6.889 & -1.473 & 0.179 & & \\
\cline { 2 - 7 } & WFC & 1.556 & 2.031 & 0.077 & 4.126 & 0.340 \\
\hline
\end{tabular}

Table 6. Output Regression for long working hours (all observations are used)

\begin{tabular}{|c|c|c|c|c|c|c|}
\hline Equation no -2 & Model & Co efficient & t-value & p-value & F-value & $\mathrm{R}^{2}$ \\
\hline \multirow{2}{*}{ Hypothesis -2 } & Constant & 0.119 & 0.218 & 0.830 & 54.064 & 0.750 \\
\cline { 2 - 5 } & WFC & 0.983 & 7.353 & 0.00 & & \\
\hline
\end{tabular}

